\title{
Mechanism of interaction between large industrial enterprises and small innovative enterprises
}

\author{
Irina Ershova ${ }^{1, *}$, Natalia Kalinina $^{1}$, and Pavel Mezentev ${ }^{1}$ \\ ${ }^{1}$ Mechanics and Machine Building Institute, Ural Federal University, Ekaterinburg, Russia
}

\begin{abstract}
The innovative development mechanisms were created based on the modern economy need for innovations, but the innovation did not happen. The research is aimed at the identification of the innovative development process problem elements, identification of the small innovative enterprise development problems and prospects, the justification of the need for innovative infrastructure attached to the higher education institution creation. The research analysed the regional and country scale statistical data. That allowed drawing conclusions on the innovative process condition, its elements, and their interrelations. In addition, the research on the small innovative enterprises was conducted. The main result of the research is the revealed "gap" between fundamental science (creating the innovation) and manufacturing enterprise, (implementation of the innovation). According to the research result, there is a need for the innovative infrastructure formation.
\end{abstract}

\section{The need for the small innovative enterprises development}

Only the innovative breakthrough will allow our country to overcome the heritage of "collapse of the 90th" and will provide "the state sovereignty" due to the innovative base creation for further successful development of all economic system. Innovations are necessary, first of all, for the enterprises making a difficult industrial output. Despite general understanding of the innovative development need of the economies in general, the separate enterprises, and also active innovative projects public financing, noticeable growth of innovative activity doesn't take place. For innovative development ensuring such structural and organizational forms as science and technology parks, industrial science and technology parks, technopolises, clusters were at different times offered.[1,2,3] The small innovative enterprises (SIE) at the higher education institution creation is one of the instruments for the innovative development crisis overcoming [4]. In 2009 there was a Federal law 02.08.2009 N 217-FZ [5], allowing for the higher education institutions and scientific research institutes to create the small innovative enterprises. As showed the statistical data analysis, there were more than 60 small innovative enterprises (SIE) with Urals Federal University participation in 2012 [6]. Nowadays there are more than 80 small innovative enterprises. But the intensive industry innovation growth in the Ekaterinburg city or in Urals region didn't follow. The created innovative enterprises didn't give multiplicative effect of the innovative production volume gain. The term small innovative enterprises (SIE) isn't a new one, it was used before the Federal law 02.08.2009 N 217-FZ was pass an act [5]. Therefore we consider necessary to specify: in this article we will understand the enterprise created with participation of the scientific organization (the higher education institution or scientific research institute) for the purpose of the innovative product commercialization as the term small innovative enterprises (SIE).

Analysis of the innovative activity level

Rapid growth of the SIE quantity didn't lead to the expected growth of the innovation in industrial production level. In Fig. 1 the share of a new innovative production in the gross national product (GDP) structure is presented.

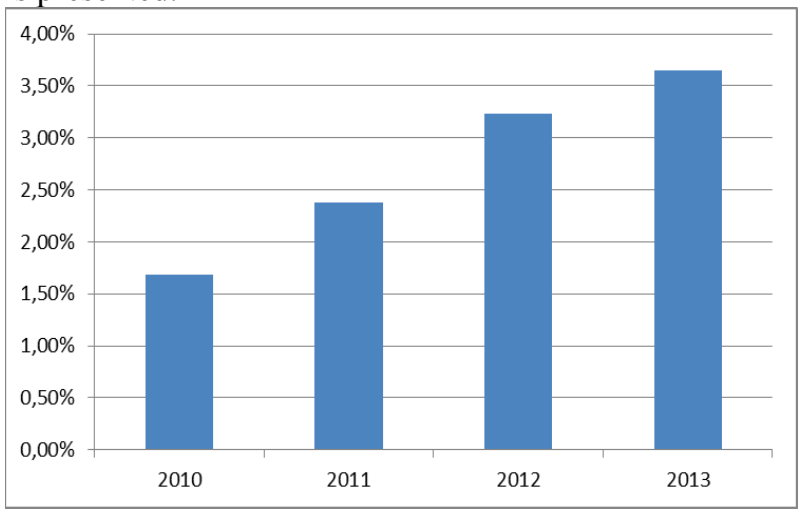

Fig. 1. The share of a new innovative production in the gross national product (GDP) structure $[7,8]$.

The share of innovative goods, services which are introduced for the first time or being exposed to considerable technological changes, in GDP is 3,5\% in 2013. So it is possible to draw a conclusion on the

\footnotetext{
Corresponding author: eiv.eopm@e1.ru
} 
insufficient level of innovative production introduction. Such situation demands further work in the sphere of ensuring communication between innovative developers and producers of an industrial output.

We will consider the main results of the enterprises activity in the Ural federal district for 2012. Ural federal district is one of the industrial regions of the country (table).

Table 1. The main results of the enterprises activity in the ural federal district for 2012 [7].

\begin{tabular}{|c|c|}
\hline Indexes & \\
\hline $\begin{array}{l}\text { On a total indicator of volume of } \\
\text { the shipped goods, by types of } \\
\text { economic activity - "the } \\
\text { processing productions",[a place, } \\
\text { million rubles]. }\end{array}$ & $\begin{array}{l}\text { 4-e } \\
3211212\end{array}$ \\
\hline $\begin{array}{l}\text { On an index of industrial } \\
\text { production, [place, } \% \text { ] }\end{array}$ & $\begin{array}{l}8-\mathrm{e} \\
101.3\end{array}$ \\
\hline $\begin{array}{l}\text { On an index of industrial } \\
\text { production, by types of economic } \\
\text { activity - "the processing } \\
\text { productions", [a place, \%] }\end{array}$ & $\begin{array}{l}2-\mathrm{e} \\
107.9\end{array}$ \\
\hline $\begin{array}{l}\text { The number of organizations } \\
\text { which are engaged in scientific } \\
\text { development, [a place, units] }\end{array}$ & $\begin{array}{l}\text { 5-e } \\
236 \quad(3566-\text { about } \\
\text { the country in } \\
\text { general) }\end{array}$ \\
\hline $\begin{array}{l}\text { The occupied with scientific } \\
\text { researches personnel in number, } \\
\text { [a place, number of people] }\end{array}$ & $\begin{array}{l}5 \text {-e } \\
43879 \quad(726318 \\
\text { about the country in } \\
\text { general) }\end{array}$ \\
\hline $\begin{array}{l}\text { Own financing } \text { of } \text { basic } \\
\text { researches, [place, one million } \\
\text { rub]. }\end{array}$ & $\begin{array}{l}6-\mathrm{e} \\
3832.6\end{array}$ \\
\hline $\begin{array}{l}\text { Own financing of } \\
\text { researches, [place, } \\
\text { rubles]. }\end{array}$ & $\begin{array}{l}\text {-e } \\
3084.5\end{array}$ \\
\hline $\begin{array}{l}\text { Is given patent applications, } \\
\text { [place, pieces] }\end{array}$ & $\begin{array}{l}7-\mathrm{e} \\
2326(42180 \text { about } \\
\text { the country in } \\
\text { general) }\end{array}$ \\
\hline $\begin{array}{l}\text { Is given out patents, [place, } \\
\text { pieces] }\end{array}$ & $\begin{array}{l}\text { 5-e } \\
1994 \text { (33633 about } \\
\text { the country in } \\
\text { general) }\end{array}$ \\
\hline $\begin{array}{l}\text { Level of inventive activity, } \\
\text { [place] }\end{array}$ & 8 -e \\
\hline $\begin{array}{l}\text { The volume of the innovative } \\
\text { goods, works, services,[place, } \\
\text { million rubles]. }\end{array}$ & $\begin{array}{l}5-\mathrm{e} \\
148696.2 \\
(2872905.1 \text { about } \\
\text { the country in } \\
\text { general }\end{array}$ \\
\hline $\begin{array}{l}\text { Share of the innovative goods, } \\
\text { works, services in total } \\
\text { production, [a place, \%]. }\end{array}$ & $\begin{array}{l}8-\mathrm{e} \\
2.1 \quad(8 \text { about the } \\
\text { country in general })\end{array}$ \\
\hline
\end{tabular}

The table is made up by authors on the basis of the data presented in the form of annual reports on the site of Federal State Statistics Service.

It should be noted that Ural federal district is the smallest industrial region, as on population (the 6th place), and on the area. Despite the modest sizes, rather small amount of the population, the region possesses enormous experience of industrial development, scientific support of production that is caused by historical, natural, resource aspects - all this allows the region to reach good results now: for example, the 2nd place on the level of industrial production. Despite rather high the level of the industrial output production, and also the level of the industrial production index, the level of the innovative activity in the region is insufficient, and on the volume of innovative production, works and services introduction Ural federal district is on the last places in comparison with the other regions.

Thus the Ural federal district industrial complex is one of the largest in the country. But this complex was created for a long time ago and initially created under the military purposes. In modern conditions a survival of such industrial region as Ural federal district demands increase of its enterprises and productions competitiveness that depends only on the success of the existing industries and productions innovative updating. It should be noted that Ural federal district differs in the smallest difference of the submitted patent applications and the taken-out patents, that testifies to the scientists and sciences schools of the region quality.

At the available requirements of the industrial development, including level of industrial production, a share of an industrial output, at the level of the region we again see the lack of due introduction into production created, introduced innovations.

It is necessary to look for the reasons which led to a low introduction of the innovative development, technologies, products. Over the past few years financing level essentially didn't change, and the number of the enterprises which are engaged in scientific development essentially didn't change. According to Federal State Statistics Service, the level of inventive activity (measured by coefficient of inventive activity and equal to number of the domestic patent applications for inventions submitted in Russia per 10 thousand people of the population) essentially didn't change for the last 3 years and makes 2 units. Thus, we can't speak about decrease in the inventive level or the number of inventions, lack of the worked system of bringing results of scientific researches to production is available.

\section{Reasons of the low efficiency of the small innovative enterprise}

For the identification and assessment of the small innovative enterprise low efficiency reasons the research in the form of questioning was conducted. About 50 small innovative enterprises took part in the research. The results of the questioning are given below.

Following the research results, it is possible to draw a conclusion that the activity of the greatest number of the small innovative enterprises is connect with IT. To some extent their production is based on the innovation creation in the field of the software, collecting, processing, storage and transfer of information. The share of the small innovative 
enterprises created for commercialization of the technological or grocery innovations in the field of industrial production doesn't exceed 5-7\%. Such situation doesn't correspond to the market requirements according to the data provided in Strategy of Sverdlovsk region development till 2020[9], the enterprises of Sverdlovsk region stated the greatest interest in innovations in the field of production technologies (for the industrial enterprises), power - and resource-saving, and information technologies take only the 3rd place.

Current situation can be characterized as inadmissible: on the one hand, the innovations commercialization mechanism is created and function, there is a requirement in technological innovation, on the other hand, innovations are offered in those spheres which are least interesting to the consumer (in this case to the industrial enterprise). Inconsistency of two subjects of the innovative market actions: small innovative enterprises and the industrial enterprises, doesn't give the chance to effectively rise of the region's innovative level.

In the questionnaire was a question: with what difficulties the company (small innovative enterprise) faces during a first or second year of its existence? Practically all participants noted the need of observance the formal rules of the company working: balance sheets, paperwork, receiving allowing documents, maintaining documentation on emergency, etc. Analyzing the received information, it is possible to speak about two main conclusions:

1. The small innovative enterprises haven't enough support of the higher education institution only as a cofounder, creation of the structure which would provide the small innovative enterprises activity is necessary. In our opinion it can be the structure similar on the functions to science park, technopark, business-incubator, etc.

2. It is necessary to analyse the purposes and problems of the small innovative enterprises creation on the point of view of all the innovative development process participants.

We will consider the need of ensuring the small innovative enterprises activity. What the purposes, tasks didn't face the small innovative enterprise; the similar form of activity assumes formation of the legal entity. The small innovative enterprise as the legal entity has to conduct the activity according to norms and laws of the Russian Federation, i.e. to keep accounting and tax account, to hand over reporting forms, to deal with issues of employment, intellectual property etc. On the other hand, as practice shows, the small innovative enterprise is created by idea carriers, research associates. In the majority they are far from questions of economy and law. As a result, the head of such enterprise has to make a choice between two variants: he understands all subtleties of legal and economic existence of the organization, or forms the team capable to solve all range of questions (Fig. 2).

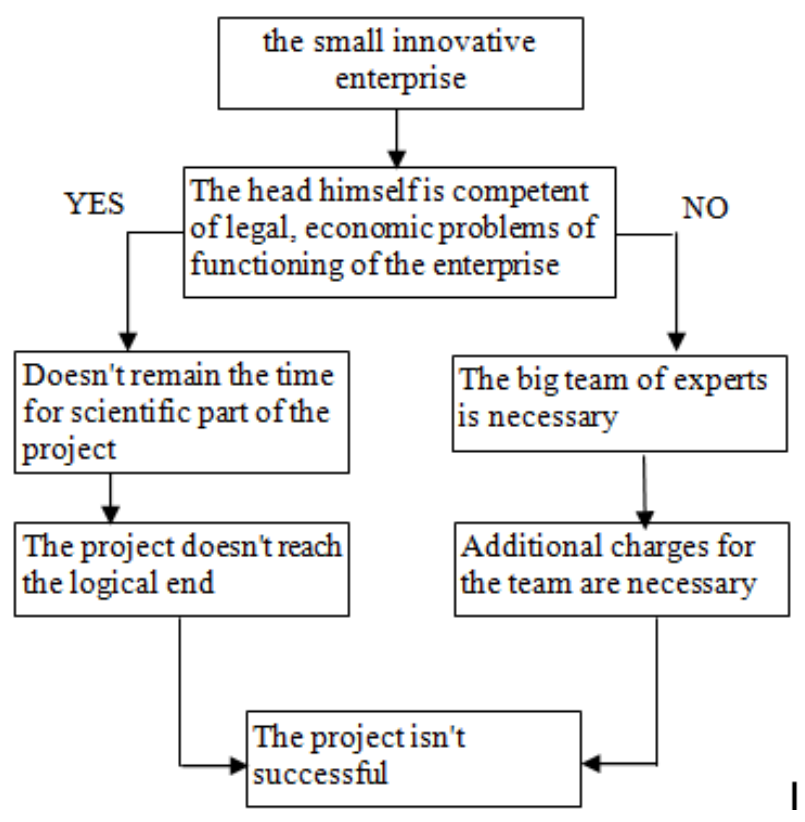

Fig. 2. Forms of the small innovative enterprise functioning.

Apparently the both forms presented at a figure lead to decrease in the project efficiency or its total failure. We consider that for increase of the small innovative enterprise overall performance it is necessary to create a structure which would assume the part of the enterprise ensuring activity tasks. For identification of such concept we suggest to define this system - "innovative infrastructure".

\section{The mechanism of the small innovative enterprises interaction with the environment}

It should be noted that except the described problem there is a feature in the relationship system between the production workers and scientists. As practice shows, they speak "different languages" what lead to misunderstanding. From our point of view the buffer, the intermediate stage is necessary. This stage will allow to connect the requirements of manufacturing enterprise and the possibilities of the scientific organizations. For example, the enterprise has a problem with the low efficiency of the used technological process or there is a need the import accessories replacement of. At the same time in the higher education institution innovative materials and ways of their processing developments are conducted. If the new material will be directly offered to the enterprise, it will be rather difficult to estimate effect of the innovative material using. The enterprise needs "finished product", for example, the developed technology which can be introduced in production with the minimum completions. In this regard a mechanism allowing "to join" participants of the innovations transfer process from developers to producers is actual. The innovative infrastructure uniting small innovative enterprise can become such mechanism.

The offered interaction mechanism is presented at Fig. 3. 


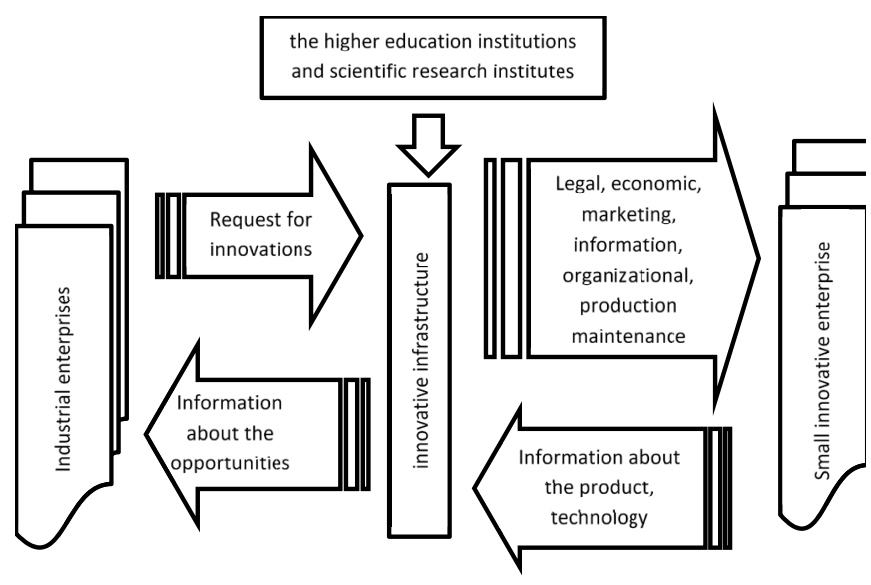

Fig. 3. Interaction of the innovative infrastructure, the small innovative enterprises and the industrial enterprises.

Realization of such mechanism will allow to increase significantly the transfer of innovative development to production system effectiveness.

\section{Life cycle of the small innovative enterprise}

There is a problem interfering effective operation of the small innovative enterprises like an instrument of innovative development of the country. As showed the conducted survey, most (about 90\%) of the small innovative enterprises owners consider it as a long or even the "eternal" project. This situation is not absolutely corresponding the the innovative enterprises development theory. According to the theory of competitive strategy (the author is A.Yu.Yudanov [10]) the small innovative enterprises relate to the explerent ("swallow"). Their possible ways of development are presented at the Fig. 4.

Apparently from the presented scheme, explerent have three ways of the life cikle: bankruptcy, slow development in a patient or in a violent and sale. Most of small innovative enterprises' founders don't consider option of sale in both variants - sale of a product or sale of a technology. The statistics shows that only $5-7 \%$ of explerent can become at least patents, the stage of violent only1-2\% of explerents can reach. Such "the low survival" is inadmissible in the conditions of sharp need for innovative development of national economy and production, and also is unacceptable for the higher education institution as for the co-owner of the small innovative enterprises.

One more important parameter - it is impossible to create the new enterprise, new plant for each innovation. It is impossible to create the new enterprise for each innovative idea, because the costs of their creation and the contents will exceed effect from their existence.

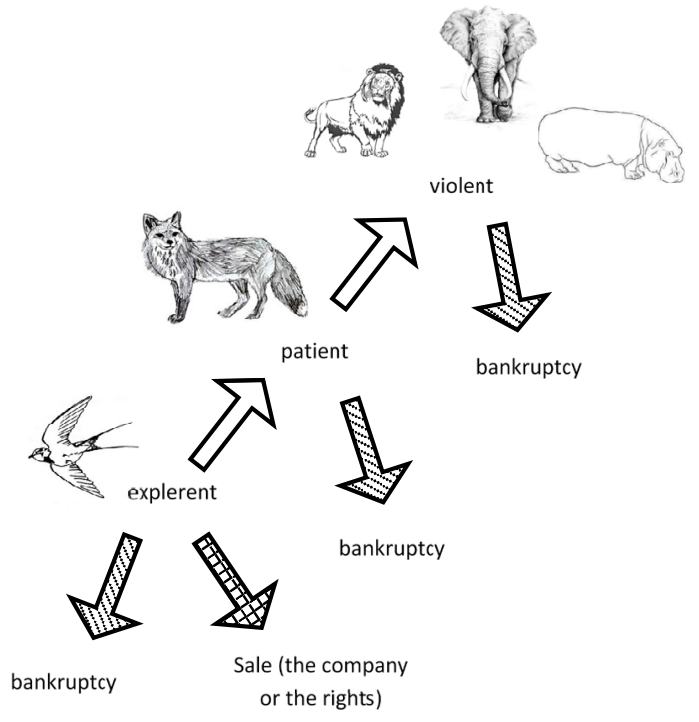

Fig. 4. The type competitive strategy evolution.

On the other hand, the same theory of competitive strategy says that violent in a condition of an elephant and hippopotamus is compelled to look for the ways and the tools for improvement of their products and technologies. In this situation, the innovations developed to a condition of a product within explerent, can be successfully sold to violent that will create mutually advantageous conditions for further development: the violent will have an opportunity to use innovations in the production, and the explerent will have resources for continuation of scientific and innovative activity.

For effective interaction of the small innovative enterprises - explerents and the industrial enterprises violent (or patient) the innovative infrastructure has to act as the guarantor of safety, honesty and efficiency of transactions on an innovative product and technology sale. This fact once again confirms validity and relevance of the innovative infrastructure creation.

\section{The main conclusions following the results of the conducted research}

Following the results of the conducted research it is possible to draw the following conclusions:

- The rapid growth of innovative development didn't occur despite the created conditions;

- The small innovative enterprise as the subject of the innovative development was created with the purpose to commercialize scientific results, but the process is going extremely slowly;

- The created small innovative enterprise "wallowed" in the solution of routine problems of the legal entity functioning;

- Founders of the small innovative enterprises consider only one variant the company development- gradual transformation into a patient (or a violent) and that is impossible under objective laws of the economic and production systems development.

On the basis of the conclusions we can speak about the need of the innovative infrastructure creations. The 
innovative infrastructure provides the small innovative enterprise activity, and the effective interaction the small innovative enterprises with potential customers of innovative development.

\section{References}

1. E.Yu. Kuznetsova, The Organizer of production, 1, 37-43 (2011)

2. I.V. Ershova, I.V. Kopytov, Questions of management, 11, 48-53 (2010)

3. C. Grimpe, K. Hussinger, Formal and Informal Technology Transfer from Academia to Industry: Complementarity Effects and Innovation Performance. http://ftp.zew.de/pub/zewdocs/dp/dp08080.pdf

4. S.Yu. Alexandrova, The small innovative enterprises at higher educational institutions of the Russian Federation (Bauman Moscow State Technical University, Moscow, 2012)
5. The federal law 2009 no. 217-FZ, About modification of separate acts of the Russian Federation concerning creation of economic societies by the budgetary scientific and educational institutions for practical application (introduction) of results of intellectual activity

6. Innovative infrastructure of the Ural Federal University http://www .inno.urfu.ru/

7. Federal State Statistics Service: official site. http://www.gks.ru/

8. The Global Innovation Index 2014. The Human Factor in Innovation. http://www .globalinnovationindex.org/content.aspx? page=giifull-report-2014

9. Strategy of innovative development of Sverdlovsk region for the period till 2020. The Regional newspaper is approved by the resolution of the government of Sverdlovsk region of 2013 646-PP (2013)

10. A.Yu. Yudanov, Competitiveness: theory and practice (GNOM\&D, Moscow, 2001) 